\title{
Does Clarithromycin Use in Acute Viral Bronchiolitis Shorten Length of Hospital Stay?
}

\begin{tabular}{|c|c|c|}
\hline Author(s) & \multicolumn{2}{|c|}{ (D) Gülnur Esenülkü1, (D)Fatma Hancı² } \\
\hline Affiliation(s) & $\begin{array}{l}\text { 1Sağlık Bilimleri Üniversitesi, Tra } \\
\text { Trabzon, Türkiye } \\
{ }^{2} \text { Abant İzzet Baysal University, F }\end{array}$ & $\begin{array}{l}\text { tim Araştırma Hastanesi, Pediatri Anabilim Dalı, } \\
\text { n of Child Neurology, Bolu, Turkey }\end{array}$ \\
\hline $\begin{array}{c}\text { Article } \\
\text { Information }\end{array}$ & $\begin{array}{l}\text { Article Type: Original Articles } \\
\text { Article Group: Pediatric Pulmonology }\end{array}$ & $\begin{array}{l}\text { Received: } 30.05 .2020 \\
\text { Accepted: } 08.09 .2020 \\
\text { Available Online: } 30.09 .2020\end{array}$ \\
\hline
\end{tabular}

Cite this article as: Esenülkü G, Hancı F. Does Clarithromycin Use in Acute Viral Bronchiolitis Shorten Length of Hospital Stay?. J Pediatr Acad 2020; 1(2): 62-65.

\section{Abstract}

Acute bronchiolitis is the most common cause of hospitalization among infants. Although antibiotics are not recommended in the absence of secondary bacterial infection, rates of antibiotic usage is high rate in clinical practicesTo test the hypothesis that clarithromycin use in infants with acute viral bronchiolitis shortens length of hospital stay.One hundred sixty-seven patients aged 1-24 months hospitalized for treatment with a diagnosis of acute viral bronchiolitis at pediatric clinic between April 2017 and May 2018 were investigated retrospectively. The patients were divided into two separate groups, Group A (122 patients), using clarithromycin therapy during hospitalization, and Group B (45 patients), which did not receive clarithromycin (Group B). Demographic and clinical data, treatments received, and duration of hospital stay were obtained from patients' records. The rate of clarithromycin use in this study was $73 \%$. No statistically significant difference in length of hospital stay was determined between patients receiving clarithromycin and those receiving no antibiotic therapy. However, length of hospital stay decreased with age. Clarithromycin use elicited no statistically significant decrease in hospital stay in patients with acute viral bronchiolitis. The routine use of clarithromycin is not recommended in acute viral bronchiolitis in the light of its cost and side-effects, and the fact is has no impact on clinical status and hospital stay.

Keywords: Acute bronchiolitis, infant, clarithromycin

Correspondence: Fatma Hancı, Abant İzzet Baysal University, pediatrics, Division of child neurology, Gölköy kampüsü, Bolu, Türkiye

E-mail: fatmah.arslan@gmail.com 


\section{Introduction}

Bronchiolitis is a severe, life-threatening lower respiratory tract infection generally affecting infants..$^{1,2}$ Acute bronchiolitis is the most common cause of hospitalization among infants younger than six months. ${ }^{3}$ The most common agent is respiratory syncytial virus (RSV). ${ }^{4}$ It can also be caused by rhinoviruses, influenza virus, parainfluenza viruses, coronaviruses, metapneumovirus, and rarely by other respiratory tract viruses. Antibiotics are not recommended in the absence of secondary bacterial infection. ${ }^{5,6}$ However, antibiotic use rates of $34-99 \%$ are reported even in non-complicated acute bronchiolitis. Antibiotic use rates of $34 \%, 45 \%$ and $99 \%$ have been reported in hospitalized infants who do not need mechanical ventilator support. ${ }^{7-10}$ One outpatient clinic study reported that antibiotics were used by $53 \%$ of children with bronchiolitis. ${ }^{11}$

Reported outcomes of the use of antibiotics in acute viral bronchiolitis in previous studies include no significant

Highlight
- Antibiotic use rates of 34-
$99 \%$ are reported even
in non-complicated acute
bronchiolitis.
- Clarithromycin use elicited
no statistically significant
decrease in hospital stay
in patients with acute viral
bronchiolitis.
- The routine use of
clarithromycin is not
recommended in acute
viral bronchiolitis.

having mild-moderate acute viral bronchiolitis. Patients with chronic heart disease, asthma, pneumonia, cystic fibrosis, or prematurity-related bronchopulmonary dysplasia, or aged over two years or under one month were excluded.

No mechanical ventilator or advanced oxygen support were required. Oxygen saturations were measured using pulse oximetry. Patients discharged in a healthy condition were enrolled.

The patients were divided into two groups. Group A, using clarithromycin therapy during hospitalization, and Group B, which did not receive clarithromycin. Two groups were first established on the basis of clarithromycin use (yes/no).

\section{Ethical Committee Approval}

Approval for the study was granted by Trabzon Kanuni Education And Research Hospital Ethical Committee (No:2018/07).

\section{Statistical analysis}

difference in severity of symptoms (decreased respiratory difficulty, feeding difficulty, and respiration rate, or restoration of social smiling), no statistically significant difference in terms of mean length of hospital stay, and no acceleration of healing, while unnecessary antibiotic use was also described as a financial burden leading to iatrogenic side-effects and resistant microorganisms. ${ }^{12-15}$ However, one study reported significant decreases in oxygen and intravenous fluid support requirements in patients receiving clarithromycin compared to placebo. The duration of beta-2 agonist use was also shorter in the clarithromycin group, and repeat hospitalization rates were lower. ${ }^{16}$

This study determined the incidence of clarithromycin use in acute viral bronchiolitis and compared patients using clarithromycin with those not receiving it in terms of duration of hospitalization.

\section{Materials and Methods}

Patients with a diagnosis of acute viral bronchiolitis at pediatric clinic between April 2017 and May 2018 were investigated retrospectively. Demographic and clinical data, treatments received, and duration of hospital stay were obtained from patients' records. One hundred sixty-seven patients aged 1-24 months, diagnosed with acute viral bronchiolitis on the basis of clinical and physical examination findings (history of fever, nasal discharge, cough, respiratory difficulty, and feeding difficulty, and presence of tachypnea, tachycardia, and rhonchi at physical examination), laboratuar findings and if necessary chest Xray, hospitalized. Patients who received inhaler beta 2 agonists, intravenous (IV) fluid support, and inhaler or oral steroid therapy, and with no chronic disease were included in the study. Acute bronchiolitis classified mild, moderate and severe. ${ }^{17}$ All patients were selected from among subjects recorded as
Univariate associations between medication use and patient characteristics were assessed using the MannWhitney $U$ or chi-square tests, based on the structure of the data. A Poisson regression model was then applied to compare the predictive ability of medication use on length of stay in hospital, after adjusting for age, gender and season. Poisson regression is appropriate when the dependent variable consists of numerical data (e.g. length of stay). The analyses were performed using the Statistical Package for Social Sciences 25.0 for Windows (SPSS Inc., Chicago, Illinois, USA). The results were assessed at a level of $p<0.05$ significance.

\section{Results}

Boys constituted 99 (59.2\%) of our patients and girls 68 $(40.8 \%)$. The patients were divided into two separate groups, Group A (122 patients), using clarithromycin therapy during hospitalization, and Group B (45 patients), which did not receive clarithromycin (Group B). Mean age for Group A was 12.6 \pm 6.6 months and $13.3 \pm 5.0$ months for Group B. Mean length of hospital stay was $4.2 \pm 2.4$ days for Group A and $4.3 \pm 2.1$ days for Group B. The rate of clarithromycin use in this study was $73 \%$. Seventy-three percent of one hundred sixty-seven patients with acute viral bronchiolitis, aged 1-24 months and admitted to hospital, were started on clarithromycin therapy. Univariate analysis was used to identify any significant relation between clarithromycin use and patient characteristics [length of hospital stay (days), age (months), gender, season] (Table). No statistically significant difference was determined using clarithromycin and those using no antibiotic. We revealed no significant relation between clarithromycin use and patient characteristics. Medication use was not a statistically significant predictor of the length of hospital in terms of length of hospital stay between patients 
stay. Neither gender nor season exhibited statistically significant correlation with length of hospital stay.

\begin{tabular}{|c|c|c|c|}
\hline \multirow[b]{2}{*}{ Patient characteristics } & \multicolumn{2}{|c|}{ Clarithromycin } & \\
\hline & No $(n=45) B$ & Yes $(n=122) A$ & $p$ \\
\hline Length of stay (days) & & & 0.387 \\
\hline Mean (SD) & $4.3 \pm 2.1$ & $4.2 \pm 2.4$ & \\
\hline Median(IQR) & $4.0 \pm 2.5$ & $3.0 \pm 2.0$ & \\
\hline Age (months) & & & 0.302 \\
\hline Mean (SD) & $13.3 \pm 5.0$ & $12.6 \pm 6.6$ & \\
\hline Median(IQR) & $13.0 \pm 6.0$ & $12.0 \pm 9.3$ & \\
\hline Gender, n (\%) & & & 0.410 \\
\hline Female & $16(35.6)$ & $52(42.6)$ & \\
\hline Male & $29(64.4)$ & $70(57.4)$ & \\
\hline Season, $\mathrm{n}(\%)$ & & & 0.283 \\
\hline Spring & $5(11.1)$ & $7(5.7)$ & \\
\hline Summer & $2(4.4)$ & $12(9.8)$ & \\
\hline Fall & $23(51.1)$ & $51(41.8)$ & \\
\hline Winter & $15(33.3)$ & $52(42.6)$ & \\
\hline
\end{tabular}

Continuous variables are expressed as mean \pm standard deviation and median \pm interquartile range, and groups were compared using the Mann Whitney $U$ test. Categorical variables were expressed as frequency (percentage) and were compared using the chi-square test.

Multivariate analysis using Poisson regression was used to determine whether clarithromycin use is a statistically significant predictor of length of hospital stay. Neither gender nor season was correlated with length of stay. However, age had a significant effect on length of hospital stay. We observed a $2.1 \%$ decrease in length of hospital stay for each increasing month of age $(p=0.001,95 \mathrm{Cl} \%$ for $\mathrm{e} \beta$ : 0.966, 0.991).

\section{Discussion}

Several retrospective and prospective studies comparing patients with acute viral bronchiolitis using antibiotics such as azithromycin, clarithromycin, erythromycin, and ampicillin with patients not using antibiotics have shown that antibiotic use makes no positive contribution to clinical improvement or length of hospitalization.

Pinto LA, et al. compared azithromycin and placebo in 184 infants and reported that azithromycin had no effect on clinical improvement or length of hospital stay in patients with acute bronchiolitis. Routine use is not recommended in patients with acute bronchiolitis since this can cause drug resistance..$^{18}$ In agreement with that study, clarithromycin did not affect length of hospitalization in patients with acute viral bronchiolitis in our study.

In a study of 52 infants, Field et al. ${ }^{12}$ observed no difference in terms of severity of symptoms between patients using ampicillin and those using placebo. They concluded that antibiotic use did not accelerate healing, and also emphasized that unnecessary antibiotic use resulted in cost problems, iatrogenic side-effects and resistant micro-organisms. Similarly, we observed that clarithromycin made no positive contribution to patients' clinical status and had no effect on length of hospital stay.
Kneyber et al..$^{13}$ reported that approximately half of 71 infants hospitalized due to RSV bronchiolitis received parenteral antibiotic therapy but that antibiotic use did not shorten length of stay in mild or moderate RSV bronchiolitis. No statistically significant difference was observed in mean length of hospital stay between patients using azithromycin and those using placebo. We also observed no decrease in mean length of hospital stay with oral/iv clarithromycin use in our study of 167 patients with mild and moderate acute viral bronchiolitis.

In their randomized controlled study of 126 patients aged 1-2 months and hospitalized with viral bronchiolitis, Mazumder et al. ${ }^{14}$ divided their subjects into three groups - receiving IV ampicillin, oral erythromycin, or no antibiotics. No significant difference was observed between these three groups in terms of clinical findings (decreased respiratory difficulty, feeding difficulty, and respiration rate, and return of social smiling). Kabir et al. ${ }^{15}$ compared three groups using parenteral ampicillin, oral erythromycin, and receiving no antibiotics. They also determined to difference in terms of clinical outcomes and lengths of hospital stay. Hamid et al. ${ }^{19}$ examined 100 patients with acute viral bronchiolitis in a retrospective study. No positive contribution to healing at clinical follow-up or significantly significant difference in length of hospital stay was observed between the group using iv or oral antibiotics and the no antibiotic group. McCallum et al. ${ }^{20}$ compared patients receiving a single dose of azithromycin with a placebo group, and determined no significant variation in patients' clinical improvement or length of stay at hospital. Our findings were compatible with those of these previous studies.

In a letter to a medical journal, McCallum et al. ${ }^{21}$ reviewed seven different studies and suggested that prospective studies examining the relation between acute viral bronchiolitis and macrolide use in infants were henceforth unnecessary. However, we think that retrospective studies are still needed in order to emphasize that macrolides or other antibiotics are not required in acute viral bronchiolitis.

Only one study reported positive effects of clarithromycin in acute RSV bronchiolitis. In a study of 21 patients with RSV bronchiolitis published in 2007, this study reported that lower oxygen and intravenous fluid support requirements in patients receiving clarithromycin compared to placebo. ${ }^{16}$ In this study also reported shorter beta-2 agonist use in the clarithromycin group, together with a lower repeat hospitalization rate. However, that study was limited by its low patient numbers. In our study, the agents involved in acute viral bronchiolitis were unknown, and clarithromycin had no effects on length of hospitalization.

The rate of clarithromycin use among patients hospitalized with a diagnosis of acute viral bronchiolitis in our study was quite high, at $73 \%$. In agreement with most studies in the literature, we determined that clarithromycin did not shorten length of hospital stay compared to patients not receiving it. Despite the many studies showing no benefit from clarithromycin, it continues to be widely used, particularly in developing countries. The reasons for overprescription of antibiotics 
by physicians include concerns over the risk of not using them, variations in culture and therapeutic customs, patient expectations, and health policies. In the light of costs, antibiotic resistance, potential side-effects, and the fact that clarithromycin makes no positive contribution to the disease, its use in acute viral bronchiolitis is not recommended.

Acute viral bronchiolitis in this study was diagnosed on the basis of clinical findings. The limitations of the study include the fact that information was obtained retrospectively from patient records. However, the statistically adequate patient numbers in our study represent a particular advantage.

\section{Conclusion}

The widespread use of clarithromycin in acute viral bronchiolitis is of no benefit to the patients, and results in increased costs, antibiotic resistance, and undesirable side-effects. This is a problem to which a solution needs to be found, particularly in developing countries.

Ethics Committee Approval: The Ethical Committee of Erciyes University, Faculty of Medicine, approved this study (Number: 2018/07).

Informed Consent: Written informed consent was obtained from patients who participated in this study.

Peer-review: Externally peer-reviewed.

Author Contributions: All of the authors declare that they have all participated in the design, execution, and analysis of the paper, and that they have approved the final version.

Conflict of Interest: The authors have no conflict of interest to declare.

Financial Disclosure: The authors declared that this study has received no financial support.

\section{REFERENCES}

1. Spurling GK, Doust J, Del Mar CB, Eriksson L. Antibiotics for bronchiolitis in children. Cochrane Database Syst Rev. 2011;6:CD005189. [CrossRef]

2. McCallum GB, Plumb EJ, Morris PS, Chang AB. Antibiotics for persistent cough or wheeze following acute bronchiolitis in children. Cochrane Database Syst Rev. 2017;88:CD009834. [CrossRef]:

3. Wohl ME, Chernick V. State of the art: bronchiolitis. Am Rev Respir Dis. 1978;118:759-781. [CrossRef]

4. Miller EK, Gebretsadik T, Carroll KN, et al. Viral etiologies of infant bronchiolitis, croup and upper respiratory illness during 4 consecutive years. Pediatr Infect Dis J. 2013;32:950-955. [CrossRef]
5. Fitzgerald DA, Kilham HA. Bronchiolitis: assessment and evidence-based management. Med J Aust. 2004;180(8):399-404. [CrossRef]

6. Lozano JM, Wang E. Bronchiolitis. Clin Evid. 2002;(7):272-282. [CrossRef]

7. Vogel AM, Lennon DR, Harding JE, et al. Variations in bronchiolitis management between five New Zealand hospitals: can we do better?. J Paediatr Child Health. 2003;39:40-45. [CrossRef]

8. Christakis DA, Cowan CA, Garrison MM, Molteni R, Marcuse E, Zerr DM. Variation in inpatient diagnostic testing and management of bronchiolitis. Pediatrics. 2005;115:878-884. [CrossRef]

9. Thorburn K, Harigopal S, Reddy V, Taylor N, van Saene HK. High incidence of pulmonary bacterial co-infection in children with severe respiratory syncytial virus (RSV) bronchiolitis. Thorax. 2006;61:611-615. [CrossRef]

10. Kabir ML, Haq N, Hoque M, et al. Evaluation of hospitalized infants and young children with bronchiolitis - a multi centre study. Mymensingh Med J. 2003;12:128-133. [CrossRef]

11. Halna M, Leblond $P$, Aissi $E$, et al. Impact de la conférence de consensus sur le traitement ambulatoire des bronchiolites du nourrisson [Impact of the consensus conference on the ambulatory treatment of bronchiolitis in infants]. Presse Med. 2005;34:277281. [CrossRef]

12. Field CM, Connolly JH, Murtagh G, Slattery CM, Turkington EE. Antibiotic treatment of epidemic bronchiolitis--a double-blind trial. Br Med J. 1966;1:83-85. [CrossRef]

13. Kneyber MC, van Woensel JB, Uijtendaal E, Uiterwaal CS, Kimpen JL; Dutch Antibiotics in RSV Trial (DART) Research Group. Azithromycin does not improve disease course in hospitalized infants with respiratory syncytial virus (RSV) lower respiratory tract disease: a randomized equivalence trial. Pediatr Pulmonol. 2008;43:142-149. [CrossRef]

14. Mazumder MJ, Hossain MM, Kabir AL. Management of Bronchiolitis with or without Antibiotics-A Randomized Control Trial. J Bangladesh Coll Phys Surg 2009;27:63-69. [CrossRef]

15. Kabir AR, Mollah AH, Anwar KS, Rahman AK, Amin R, Rahman ME. Management of bronchiolitis without antibiotics: a multicentre randomized control trial in Bangladesh. Acta Paediatr. 2009;98:1593-1599. [CrossRef]

16. Tahan F, Ozcan A, Koc N. Clarithromycin in the treatment of RSV bronchiolitis: a double-blind, randomised, placebo-controlled trial. Eur Respir J. 2007;29:91-97. [CrossRef]

17. Türk Toraks Derneği Akut Bronşiolit Tanı ve Tedavi Uzlaşı Raporu, Official journal of the Turkish Thoracic Society 2009; 10: 3-7.

18. Pinto LA, Pitrez PM, Luisi F, et al. Azithromycin therapy in hospitalized infants with acute bronchiolitis is not associated with better clinical outcomes: a randomized, double-blinded, and placebo-controlled clinical trial. J Pediatr. 2012;161:1104-1108. [CrossRef]

19. Hamid F, Quaium SM, Rahman A, et al. Audit on the Management of Bronchiolitis: A Single Centre Real World Experience in Bangladesh. Can We do Better ? Chattagram Maa-O-Shishu Hospital Medical College Journal 2015;14:6-10. [CrossRef]

20. McCallum GB, Chang AB, Grimwood K. Further clinical trials on macrolides for bronchiolitis in infants are unnecessary. $J$ Allergy Clin Immunol. 2015;136:1134-1135. [CrossRef]

21. McCallum GB, Morris PS, Chatfield MD, et al. A single dose of azithromycin does not improve clinical outcomes of children hospitalised with bronchiolitis: a randomised, placebo-controlled trial. PLoS One. 2013;8:e74316. [CrossRef] 